\title{
Enhancement of Muscle T Regulatory Cells and Improvement of Muscular Dystrophic Process in $m d x$ Mice by Blockade of Extracellular ATP/P2X Axis
}

\author{
Elisabetta Gazzerro, ${ }^{*}$ Simona Baldassari, ${ }^{*}$ Stefania Assereto, ${ }^{*}$ Floriana Fruscione, ${ }^{*}$ Angela Pistorio, ${ }^{\dagger}$ Chiara Panicucci, ${ }^{*}$ \\ Stefano Volpi, ${ }^{\ddagger}$ Lisa Perruzza, ${ }^{\S 币}$ Chiara Fiorillo, Carlo Minetti, ${ }^{*}$ Elisabetta Traggiai, ${ }^{* *}$ Fabio Grassi, ${ }^{\S \dagger \dagger}$ and Claudio Bruno
}

\begin{abstract}
From the Units of Pediatric Neurology and Muscle Disease, ${ }^{*}$ Epidemiology and Statistics, ${ }^{\dagger}$ and Pediatrics II, ${ }^{\ddagger}$ and the Center of Myology and Neurodegenerative Disorders, Department of Neuroscience, ${ }^{\ddagger \ddagger}$ Istituto Giannina Gaslini, Genova, Italy; the Institute for Research in Biomedicine, ${ }^{\S}$ Bellinzona, Switzerland; the Graduate School for Cellular and Biomedical Sciences, ${ }^{\top}$ University of Bern, Bern, Switzerland; the Neuromuscular and Molecular Medicine Unit," Stella Maris Foundation, Pisa, Italy; the Novartis Biologics Center, ** Novartis Institute for Research in Biomedicine, Basel, Switzerland; and the Department of Medical Biotechnologies \& Translational Medicine, ${ }^{\dagger \dagger}$ University of Milan, Istituto Nazionale di Genetica Molecolare, Milan, Italy
\end{abstract}

\author{
Accepted for publication \\ August 31, 2015. \\ Address correspondence to \\ Claudio Bruno, M.D., Ph.D., \\ Center of Myology and \\ Neurodegenerative Disorders, \\ Department of Neuroscience, \\ Istituto Giannina Gaslini, Largo \\ G. Gaslini, 5 I-16147 Genova, \\ Italy; or Fabio Grassi, M.D., \\ Ph.D., Institute for Research in \\ Biomedicine, Bellinzona, \\ Switzerland. E-mail: \\ claudiobruno@ospedale- \\ gaslini.ge.it, claudio2246@ \\ gmail.com or fabio.grassi@irb. \\ unisi.ch.
}

\begin{abstract}
Infiltration of immune cells and chronic inflammation substantially affect skeletal and cardiac muscle degeneration in Duchenne muscular dystrophy. In the immune system, extracellular adenosine triphosphate (ATP) released by dying cells is sensed as a danger associated molecular pattern through P2 purinergic receptors. Specifically, the P2X7 subtype has a prominent role in regulating immune system physiology and contributes to inflammasome activation also in muscle cells. Here, we show that in vivo blockade of the extracellular ATP/P2X purinergic signaling pathway by periodate-oxidized ATP delayed the progression of the dystrophic phenotype and dampened the local inflammatory response in $m d x$ mice, a spontaneous mouse model of dystrophin deficiency. Reduced infiltration of leukocytes and macrophages and decreased expression of IL-6 were revealed in the muscles of periodate-oxidized ATP-treated $m d x$ mice. Concomitantly, an increase in Foxp $3^{+}$immunosuppressive regulatory T cells was observed and correlated with enhanced myofiber regeneration. Moreover, we detected reduced concentrations of profibrotic cytokines, including transforming growth factor- $\beta$ and connective tissue growth factor, in muscles of periodate-oxidized ATP-treated $m d x$ mice. The improvement of inflammatory features was associated with increased strength and reduced necrosis, thus suggesting that pharmacologic purinergic antagonism altering the adaptive immune component in the muscle infiltrates might represent a promising therapeutic approach in Duchenne muscular dystrophy. (Am J Pathol 2015, 185: 3349-3360; http://dx.doi.org/10.1016/j.ajpath.2015.08.010)
\end{abstract}

Duchenne muscular dystrophy (DMD) is a devastating inherited disease of childhood, characterized by progressive muscle degeneration and weakness, leading to loss of ambulation in the early second decade of life and mortality in the thirties. ${ }^{1}$ The primary cause of this disorder is mutations in the DMD gene, which encodes a $427-\mathrm{kDa}$ protein (dystrophin) found throughout the cytoplasmic face of the plasma membrane in both skeletal and cardiac muscles. ${ }^{1}$

Dystrophin binds distinct members of the dystrophin glycoprotein complex, forming a mechanical-signaling link from the extracellular matrix to the cytoskeleton. ${ }^{2}$ Mutations in dystrophin result in a structurally weaker plasma membrane, which is more easily damaged during muscle contraction, causing necrosis, massive infiltration of immune cells, chronic inflammation, necrosis, and muscle degeneration. ${ }^{2,3}$ The secondary processes that involve persistent inflammation and impaired regeneration aggravate the disease progression and ultimately lead to connective tissue replacement.

Supported by Ministry of Health-Ricerca Corrente, Del. 50/14 13582/ 14 (E.G.), and Swiss National Science Foundation grant 310030-140963 (F.G.).

E.G. and S.B. contributed equally to this work.

Disclosures: None declared.

Current address of E.T., Novartis Institute for Research in Biomedicine (Basel, Switzerland). 
Depletion of $\mathrm{CD}_{4}{ }^{+}$and $\mathrm{CD} 8{ }^{+} \mathrm{T}$ cells,${ }^{4}$ macrophages, ${ }^{5}$ eosinophils, and neutrophils ${ }^{6}$ or treatment with immunosuppressive drugs ${ }^{7-11}$ have all been shown to improve pathogenic features of the disease. Despite these findings to indicate that the immune system critically contributes to the functional impairment of DMD patients, the molecular mechanisms that initiate and perpetuate inflammation in DMD are poorly defined.

An inflammatory response in the absence of infectious agents is initiated primarily by damage-associated molecular patterns (DAMPs). ${ }^{12}$ DAMPs are endogenous molecules, which are virtually absent in the extracellular space in physiologic conditions; once released into the extracellular space by injured cells they display disparate functions. Extracellular adenosine triphosphate (eATP) and its derivates are pleiotropic regulators of mammalian cell function, ${ }^{13}$ although they act as DAMPs when massively released by dying cells. eATP activates plasma membrane receptors for extracellular nucleotides termed P2 receptors. $\mathrm{P} 2 \mathrm{X} 1$ to $\mathrm{P} 2 \mathrm{X} 7$ receptors open nonselective ion channels, whereas P2Y1, P2Y2, P2Y4, P2Y6, and P2Y11 to $\mathrm{P} 2 \mathrm{Y} 14$ are guanine nucleotide-binding protein ( $\mathrm{G}$ protein)coupled receptors, which bind also ADP, UDP, UTP, or UDP-glucose. ${ }^{13}$ Activation of $\mathrm{P} 2$ receptors regulates many cellular functions that range from survival and proliferation to apoptosis. The final effect of eATP on a given cell depends, therefore, on the composition of $\mathrm{P} 2$ receptors expressed on its surface. $^{14,15}$

In the immune system, P2X7 receptor was extensively investigated because its activation in mouse macrophages by exogenous ATP contributes to inflammasome activation and is required as a second signal for IL- $1 \beta$ processing and secretion. ${ }^{16}$ Primary muscle cells express various $\mathrm{P} 2 \mathrm{X}$ subtypes in physiologic conditions, and substantial up-regulation of $\mathrm{P} 2 \mathrm{X} 7$ was immunodetected in skeletal muscle from $m d x$ mice (a spontaneous mouse model of dystrophin deficiency) and in myoblasts isolated from patients affected by DMD or by dysferlin deficiency. ${ }^{17-21}$ Moreover, exposure to eATP of myoblasts from $m d x$ or dysferlin knockout mice triggers an increase in cytosolic $\mathrm{Ca}^{2+}$ ions and release of IL- $1 \beta$, suggesting that muscle cells can also actively participate in the inflammatory process through purinergic signaling. ${ }^{21}$

We have previously shown that P2XR activity affects the immunosuppressive potential of regulatory $\mathrm{T}$ cells (Tregs). ${ }^{22}$ Interestingly, Tregs were recently shown to inhibit the progression of muscle damage and to improve regeneration in $m d x$ mice. ${ }^{23,24}$ Thus, in the present study we addressed whether inhibition of $\mathrm{P} 2 \mathrm{X}$ receptors could beneficially impinge on the in vivo inflammatory response associated with dystrophin deficiency and enhance Treg function.

We therefore treated $m d x$ mice with periodate-oxidized ATP (oATP), a compound that irreversibly antagonizes $\mathrm{P} 2 \mathrm{X}$ receptors through the selective modification of lysine residues in the vicinity of the ATP binding site. ${ }^{25}$ Our results point to a role of eATP in contributing to the immunopathologic damage of dystrophic muscle and to a possible beneficial effect of pharmacologic purinergic antagonism in DMD.

\section{Material and Methods}

\section{Muscle Biopsies}

All human samples were obtained after patients had signed informed consent forms in accordance with the guidelines of the Istituto Giannina Gaslini Ethical Committee, including experimental protocols for muscle biopsies.

Total RNA was isolated from muscle biopsies obtained for diagnostic purposes from seven and three patients with confirmed DMD and Becker muscular dystrophy, respectively. Hematoxylin and eosin (H\&E)-stained sections were scored for the presence of fibrosis, degeneration/regeneration, and inflammatory infiltrates, according to arbitrary criteria, by two independent pathologists.

\section{In Vivo Treatment with oATP}

B6Ros.cG-Dm $d^{m d x-4 \mathrm{Cv}} / \mathrm{J}$ ( $m d x-4 \mathrm{Cv}$, males, 4 weeks old; Charles River Laboratories, Wilmington, MA) and wildtype (WT) $\mathrm{C} 57 \mathrm{Bl} / 6 \mathrm{~J}$ mice were treated with $100 \mu \mathrm{L}$ oATP at $6 \mathrm{mmol} / \mathrm{L}$ or phosphate-buffered saline (PBS) alone every day for 2 or 4 weeks by i.p. injection and were sacrificed by carbon dioxide inhalation $(n=4$ to 8 mice for each experimental group). A group of WT age-matched $\mathrm{C} 57 \mathrm{Bl} / 6 \mathrm{~J}$ male mice was used as internal control $(n=5)$. The $m d x-4 \mathrm{Cv}$ mice were randomly assigned to experimental groups, and testing of samples collected from the studies was performed blindly (S.B. and E.G.).

The blood samples were collected by periorbital puncture at the end of the second and fourth week of treatment and centrifuged for 10 minutes at $7000 \times g$. Immediately after centrifugation, the serum was isolated and stored at $-20^{\circ} \mathrm{C}$. Creatine kinase (CK) concentrations were measured with the CK-NAC quantitative system according to the manufacturer's instructions (BPC BioSED, Rome, Italy).

All animal experiments were performed in accordance with the Swiss Federal Veterinary Office guidelines and authorized by the Animal Studies Committee of Cantonal Veterinary.

\section{Forced Treadmill Running}

Mice were subjected to chronic treadmill running with the use of an Exer 3/6-treadmill system (Columbus, $\mathrm{OH}$ ) according to standard operating procedures. ${ }^{26,27}$ Briefly, oATP-, PBS-treated $m d x-4 \mathrm{Cv}$, and WT control mice were acclimated to the treadmill for 3 days and then challenged with treadmill running twice a week for a total of 4 weeks. Each session lasted 40 minutes, including 10 minutes of warm-up at the speed of 8 miles per minute, followed by 30 minutes of running at a speed of 12 miles per minute on a horizontal treadmill (plus the extra time of the stops). At the 
end of the second and fourth week of treatment, the number of stops for each experimental group was measured.

\section{Hanging Wire Tests}

At the conclusion of the second and fourth week of treatment, the muscle strength of oATP-, PBS-treated $m d x-4 \mathrm{Cv}$, and WT control mice was scored with the hanging wire analysis through the longest suspension time-method. In the experiment, all of the mice had to hang for three trials, and the average maximum hanging time of the three trials was measured. ${ }^{28}$

\section{Vital Staining with Evans Blue Dye}

To detect damaged muscle fibers, 20 hours before the sacrifice Evans Blue Dye (EBD; stock solution; $10 \mathrm{mg} / \mathrm{mL}$ in PBS) was injected $(0.1 \mathrm{~mL} / 10 \mathrm{~g}$ body weight $)$ into the peritoneal cavity of each mouse. ${ }^{29}$ After sacrifice, the gastrocnemii (GN) were excised, immediately frozen in nitrogen-cooled isopentane, and stored for further analyses. Frozen sections, obtained by cutting the muscle on a cryostat, were observed under an Axioplan M2 Imager microscope (Zeiss, Göttingen, Germany) to detect the EBD red autofluorescence signal. EBD ${ }^{+}$fibers were quantified in two sections for each muscle ( $n=5$ mice for each experimental group) and expressed as number per $\mathrm{mm}^{2}$ of total area.

\section{Reagents and Antibodies}

oATP (Sigma-Aldrich, St. Louis, MO; A6779-25MG) was reconstituted at a final concentration of $100 \mathrm{mmol} / \mathrm{L}$ in PBS and stored at $-80^{\circ} \mathrm{C}$; the reconstituted drug was thawed and diluted in PBS at $6 \mathrm{mmol} / \mathrm{L}$ immediately before use.

The antibodies and dilutions used in the study include the following: rabbit polyclonal antibody to IL-6 (dilution 1:1000 for Western blot analysis, WB) from Abcam (Cambridge, UK). Purified rat monoclonal antibodies to CD45 [dilution 1:10 for immunohistochemistry (IHC)] was from BD Pharmingen (San Jose, CA). Purified rat antibody to Foxp3 (dilution 1:20 for IHC) was from eBioscience (San Diego, CA). Rat monoclonal antibody to F4/80 (dilution $1: 100$ for IHC), mouse monoclonal antibody to embryonal myosin heavy chain (e-MYHC) 1/2/3 (dilution 1:100 for IHC), mouse monoclonal antibody to myogenin (dilution 1:100 for IHC), rabbit polyclonal antibody to glyceraldehyde phosphate dehydrogenase (GAPDH; dilution 1:500 for WB), and goat polyclonal antibody to connective tissue growth factor (CTGF; dilution 1:500 for WB) were from Santa Cruz Biotechnology (Santa Cruz, CA). Rabbit polyclonal antibody to CD3 (dilution 1:20 for IHC) was from Dako (Glostrup, Denmark). Rabbit polyclonal antibody to transforming growth factor (TGF)- $\beta$ (dilution 1:1000 for WB) was from Cell Signaling Technology (Danvers, MA). Rabbit anti-mouse IgG horseradish peroxidase (HRP)-conjugated (dilution 1:700 for WB) was from Dako, and donkey antirabbit IgG HRP-conjugated (dilution 1:5000 for WB) was from GE Healthcare (Milan, Italy). EnVision Detection
System Peroxidase/3-3'-diaminobenzidine, rabbit and mouse, were from Dako.

\section{Histologic Studies}

Sections $(7 \mu \mathrm{m})$ from GN and anterior tibialis (A.Tib.) muscles isolated from PBS-, oATP- $m d x-4 \mathrm{Cv}$, and WT control mice were cut on a cryostat and later stained with H\&E. Cross-sectional areas (CSAs) and central nucleation were quantified in a blinded manner (S.B. and E.G.) in three sections for each muscle ( $n=5$ mice for each experimental group, $n=400$ to 600 myofibers) with ImageJ software version 1.45s (NIH, Bethesda, MD; http://imagej.nih.gov/ij) under an Axioplan M2 Imager microscope. Fiber size variability was calculated according to the formula: $\mathrm{SD} \times$ $1000 /$ mean fiber diameter. ${ }^{29}$

Paraffin-embedded diaphragms isolated from PBS-, oATP- $m d x-4 \mathrm{Cv}$, and WT control mice were cut in cross section at the mid-belly of the muscle (7- $\mu \mathrm{m}$ thickness). After deparafinization the slides were stained with H\&E. ${ }^{29}$

\section{IHC}

Five-micron thick cryosections of GN and A.Tib. muscles isolated from PBS-, oATP- $m d x-4 \mathrm{Cv}$, and WT control mice were fixed in acetone at $-20^{\circ} \mathrm{C}$ for 10 minutes, washed two times in PBS, and then in bovine serum albumin (BSA) $4 \%$ in PBS for 5 minutes. Sections were incubated in 3\% hydrogen peroxide in BSA $8 \%$ in PBS for 10 minutes at room temperature and washed for 5 minutes in BSA $8 \%$ in PBS. After two washes in BSA 4\% in PBS (blocking solution), sections were permeabilized in $0.3 \%$ Triton $\mathrm{X}-100$ in BSA 4\% in PBS and incubated with primary antibodies (for CD45, F4/80, Foxp3, and CD3) diluted in blocking solution overnight at $4^{\circ} \mathrm{C}$. The next day, sections were washed three times with BSA 4\% in PBS and then incubated with Envision secondary antibody. After being rinsed three times with PBS (5 minutes each), the sections were stained with a diaminobenzidine substrate solution (freshly made just before use), counterstained with hematoxylin, washed with deionized water, dehydrated through five changes of alcohol $(70 \%, 90 \%, 95 \%, 100 \%$, and $100 \%)$ for 1 minute each, cleared in two changes of xylene ( 3 minutes each), and mounted with a Vectashield mounting medium (Vector Laboratories; Burlingame, CA). Slides were observed under a Leica Diaplan microscope (Leica, Wetzlar, Germany). The number of positive cells was blindly counted on the whole sections per mouse (S.B. and E.G.). The total area of the section was measured and expressed in $\mathrm{mm}^{2}$.

\section{qPCR}

Total RNA was extracted from GN muscles (from 20 to 55 $\mathrm{mg}$ ) isolated from PBS-, oATP- $m d x-4 \mathrm{Cv}$, and WT control mice or from fragments of human muscle biopsies with the use of the RNeasy Lipid Tissue Mini Kit (Qiagen, Milan, 
Table 1 qPCR Human and Murine Probes

\begin{tabular}{ll}
\hline Probe & Catalog number \\
\hline hP2RX1 & Hs00175686_m1 \\
hP2RX2 & Hs04176268_g1 \\
hP2RX3 & Hs01125554_m1 \\
hP2RX4 & Hs00602442_m1 \\
hP2RX5 & Hs01112471_m1 \\
hP2RX6 & Hs01003997_m1 \\
hP2RX7 & Hs00175721_m1 \\
hGAPDH & 4333764F \\
hACTA1 & Hs00559403_m1 \\
mP2RX1 & Mm00435460_m1 \\
mP2RX2 & Mm01202368_g1 \\
mP2RX3 & Mm00523699_m1 \\
mP2RX4 & Mm00501787_m1 \\
mP2RX5 & Mm00473677_m1 \\
mP2RX6 & Mm00440591_m1 \\
mP2RX7 & Mm00440578_m1 \\
mGAPDH & $4352932 E$ \\
mACTA1 & Mm00808218_g1 \\
\hline
\end{tabular}

qPCR, quantitative real-time PCR.

Italy) and according to the manufacturer's protocol (DNase treatment). Quality and quantity of RNA were analyzed with a NanoDrop spectrophotometer.

The cDNA was synthesized from 350 ng of total RNA with the iScript cDNA Synthesis Kit (Bio-Rad Laboratories, Milan, Italy). Each RNA sample was controlled for genomic DNA contamination without reverse transcriptase addition into cDNA synthesis mixture. For Foxp3 and Amphyregulin (Areg) transcript quantification, quantitative real-time PCR (qPCR) was performed in triplicate with the $2 \times$ Sso Fast EvaGreen Supermix (Bio-Rad Laboratories) in CFX96 Real-Time PCR Detection System (Bio-Rad Laboratories).

Briefly, the 15- $\mu \mathrm{L}$ PCR mixture contained diluted cDNA that corresponded to $8.75 \mathrm{ng}$ of total RNA and $0.2 \mathrm{mmol} / \mathrm{L}$ of each primer. Relative expression levels were normalized with the comparative $\mathrm{Ct}(\Delta \Delta \mathrm{Ct})$ method with the housekeeping gene (Gapdh) by the Bio-Rad CFX manager software version 3.1. For each specific primer set, the efficiency was $>95 \%$, and a single product was seen on the melting curve analysis. Specific primers for Areg (NM_009704), Foxp3 (NM_001199347), and Gapdh (NM_008084) were designed through Beacon Designer 2.0 Software (Premier Biosoft, Palo Alto, CA). Areg: 5'-AAGGAGGCTTCGACAAGAAA-3' (forward), $5^{\prime}$-TTTACCCTGCATTGTCCTCA-3' (reverse); Foxp3: 5'-CAGTCAAAGAGCCCTCACAA-3' (forward), 5'-AAGGCAGGCTCTTCATGTTT-3' (reverse); Gapdh: 5'-AACTTTGGCATTGTGGAAGG-3' (forward), 5'-CCATCCACAGTCTTCTGGGT-3' (reverse).

For human and mouse $\mathrm{P} 2 \mathrm{X}$ receptor quantification, $\mathrm{qPCR}$ was performed in triplicate with the $2 \times$ Sso Fast Probes Supermix (Bio-Rad Laboratories) in CFX96 Real-time PCR Detection System (Bio-Rad Laboratories). The 15- $\mu$ L PCR mixture contained diluted cDNA that corresponded to 12.5 ng of total RNA, and premixed primer/probe sets were ordered from Applied Biosystems, Foster City, CA (Table 1). Relative expression levels were normalized with the $\Delta \Delta \mathrm{Ct}$ method with the housekeeping gene Gapdh and actin, $\alpha 1$, skeletal muscle (ACTA1, a muscle-specific gene NM_001272041.1), by the Bio-Rad CFX manager software.

\section{Western Blot Analysis}

Tissue samples were prepared on ice as follows: five to eight $10-\mu \mathrm{m}$-thick cryosections of GN and A.Tib. muscles isolated from PBS-, oATP- $m d x-4 \mathrm{Cv}$, and WT control mice were quickly dissolved in $40 \mu \mathrm{L}$ of RIPA lysis buffer (Sigma-Aldrich) with 1:200 protease inhibitor cocktail (Sigma-Aldrich). Tissue lysates were then sonicated for 10 seconds on ice and centrifuged at 10,621 $\times g$ for 15 minutes at $4^{\circ} \mathrm{C}$. Supernatant fluids were collected, and the protein concentration was determined with the Bradford protein assay method (Bio-Rad Laboratories). Equal amounts of protein $(40$ to $120 \mu \mathrm{g}$ ) were mixed with SDS gel-loading buffer $(100 \mathrm{mmol} / \mathrm{L}$ Tris-HCl, pH 6.8, $400 \mathrm{mmol} / \mathrm{L}$ dithiothreitol, $4 \%$ SDS, $0.2 \%$ bromophenol blue, and $20 \%$ glycerol), resolved in $6 \%$ to $15 \%$ SDS-PAGE gel, and run at

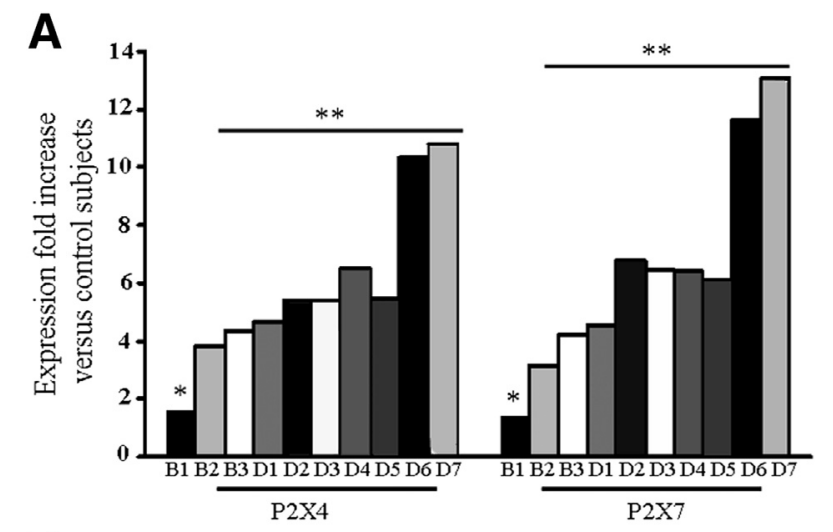

B

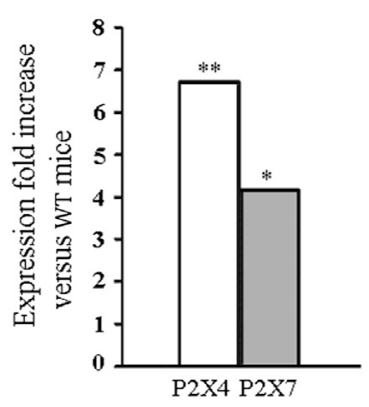

Figure 1 P2X receptors 4 and 7 are up-regulated in muscle tissue from patients affected by BMD and DMD as well as in GN from $m d x-4 C v$ mice. $A$ and B: Total RNA isolated from the muscle biopsies of three BMD (B1 to B3) and seven DMD (D1 to D7) patients and three controls, and from the GN of five $m d x-4 C v$ and four age- and sex-matched WT mice was reverse transcribed. P2X4 and P2X7 transcripts were quantified by real-time PCR. GAPDH and ACTA1 served as control. The data are expressed as folds versus the mean of controls. Statistical analysis was performed with the $U$ test. ${ }^{*} P<0.05$, ${ }^{* * P}<0.01$. ACTA1, actin, $\alpha 1$; BMD, Becker muscular dystrophy; DMD, Duchenne muscular dystrophy; GAPDH, glyceraldehyde-3-phosphate dehydrogenase; GN, gastrocnemii; WT, wild-type. 

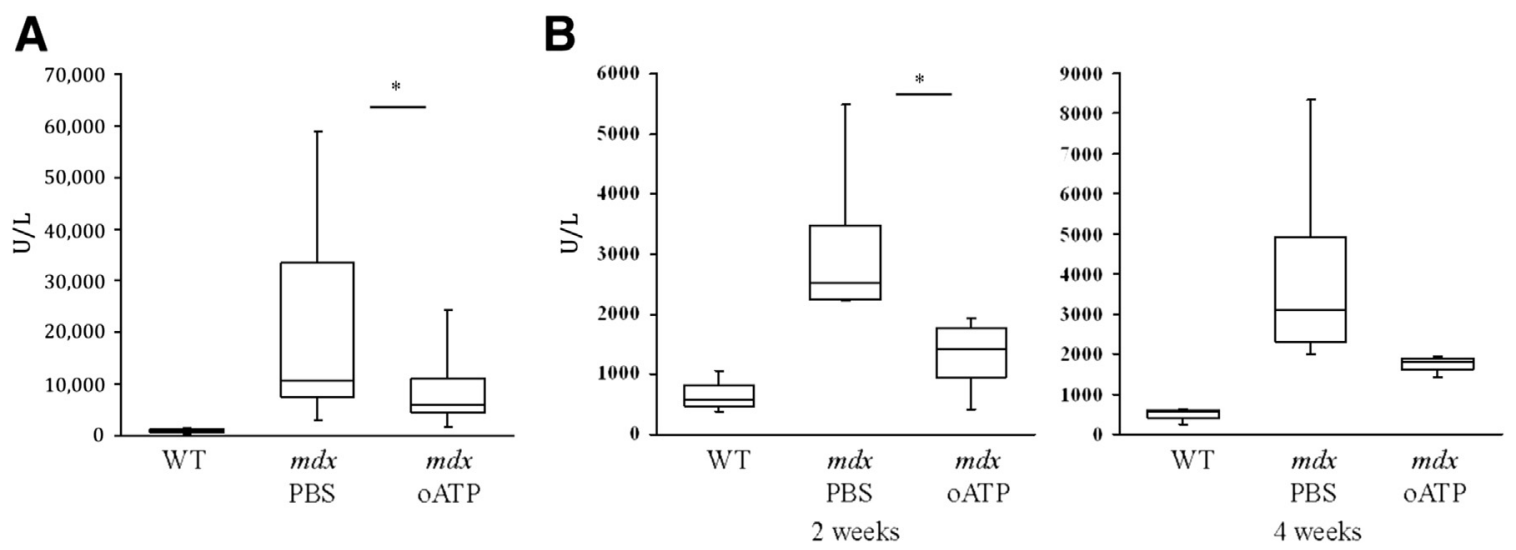

Figure 2 oATP ameliorates CK serum concentrations in resting and exercised $m d x-4 C v$ mice. A: Serum CK concentrations were evaluated in the short-term (2 weeks) experiment. Blood samples were obtained from $m d x$ oATP, $m d x$ PBS, and age-matched WT mice at the end of the treatment. B: Serum CK concentrations were evaluated in the 4-week experiment when all of the experimental groups were subjected to chronic exercise. Blood samples were obtained from $m d x$ OATP, $m d x$ PBS, and age-matched WT mice at the end of the second and fourth week of treatment. Each box represents the median with first and third quartile. $n=4$ to 8 mice (A); $n=5$ mice (B). Statistical analysis was performed with the $U$ test. ${ }^{*} P<0.05$. CK, creatine kinase; $m d x$ oATP, oATP-treated $m d x-4 C v$; $m d x$ PBS, untreated $m d x-4 C v$; oATP, periodate-oxidized ATP; PBS, phosphate-buffered saline; WT, wild-type.

$80 \mathrm{~V}$ for 2 to 2.30 hours in electrophoresis buffer $(25$ $\mathrm{mmol} / \mathrm{L}$ Tris, $250 \mathrm{mmol} / \mathrm{L}$ glycine, and $0.1 \%$ SDS). Proteins were then transferred onto polyvinylidene difluoride membranes (Immobilon PVDF; Millipore, Milan, Italy). Membranes were blocked with 5\% BSA in PBS/0.1\% Tween 20 . Blots were then incubated for 2 hours at room temperature with primary antibodies all diluted in $1 \% \mathrm{BSA} / \mathrm{PBS}$. HRP antiIgG was used to visualize bound primary antibodies with the chemiluminescence system (Bio-Rad Laboratories). Band intensities were evaluated by densitometry with the use of the ImageQuant 350 system (Amersham Biosciences, Piscataway, NY).

\section{Statistical Analysis}

Most of the analyzed variables were not normally distributed as confirmed by the Shapiro-Wilk test; therefore, differences of quantitative parameters between two groups of mice were analyzed by the nonparametric $U$ test. $P<0.05$ was considered as statistically significant. Data are expressed as median with first and third quartiles (Qs) as described in Results and the figure legends.

For the distribution of CSAs, the number of categories and range between each class was calculated according to Sturges formula. Differences between the axonal diameters corresponding to each row of bin limits were evaluated by the $\chi^{2}$ test with a further post hoc correction (Bonferroni) to avoid multiple comparison errors.

The analysis of homogeneity between variances in myofiber areas between PBS- and oATP-treated mice was calculated by Hartley's F.Max test.

All correlations were assessed with Spearman's rank order correlation coefficient (rs). Correlation coefficients were classified as follows: $r s<0.4=$ poor, $\geq 0.4$ to $0.80=$ moderate, and $\geq 0.80=\operatorname{good}$ correlation. ${ }^{30}$

Statistica software version 9.1 (StatSoft Co., Tulsa, OK) was used for all of the statistical analyses. Graphs were generated with GraphPad Prism 5.0 software (GraphPad Software, San Diego, CA).

\section{Results}

Targeting P2X Signaling in Vivo Improves Biochemical and Functional Parameters of Disease Progression in $m d x$ Mice

We initially characterized the pattern of expression of the different $\mathrm{P} 2 \mathrm{X}$ receptors in patients with different degrees of dystrophin deficiency. P2X1 to P2X7 transcript levels were quantified in the muscle biopsies of three patients with Becker muscular dystrophy, the milder allelic variant of DMD, and of seven DMD cases. The severity of disease was scored according to arbitrary histologic criteria (Supplemental Table S1). In accordance with previous studies, P2X4 and P2X7 transcripts were significantly up-regulated in all patients, although at different levels: milder Becker muscular dystrophy cases displayed a 1.6- to 4.3-fold increase, whereas the most severe DMD patients showed up to a 10.8- to 13-fold induction (Figure 1A and Supplemental Table S1). ${ }^{18-20}$ Analogously, $\mathrm{P} 2 \mathrm{X} 4$ and $\mathrm{P} 2 \mathrm{X} 7$ were increased in $\mathrm{GN}$ isolated from $m d x-4 \mathrm{Cv}$ mice and WT sex- and age-matched controls (Figure 1B).

To be able to achieve an antagonistic effect on both P2X receptors, we hence chose to treat $m d x-4 \mathrm{Cv}$ mice with oATP, which was originally described as an irreversible $\mathrm{P} 2 \mathrm{X} 7$ antagonist but was shown later to block also all other $\mathrm{P} 2 \mathrm{X}$ receptor subtypes, resulting in the improvement of immunopathology in several inflammatory mouse models. ${ }^{31-34}$

The efficacy of the compound was first tested at $6 \mathrm{mmol} / \mathrm{L}$ intraperitoneally in a short-term treatment ( 2 weeks) of 4-weekold $m d x-4 \mathrm{Cv}$ male mice. For these experiments, we chose as an end point serum CK concentrations because they reflect and correlate with active muscle degeneration. Intriguingly, oATP treatment led to a $44 \%$ reduction in serum CK in PBS- $m d x-4 \mathrm{Cv}$ 

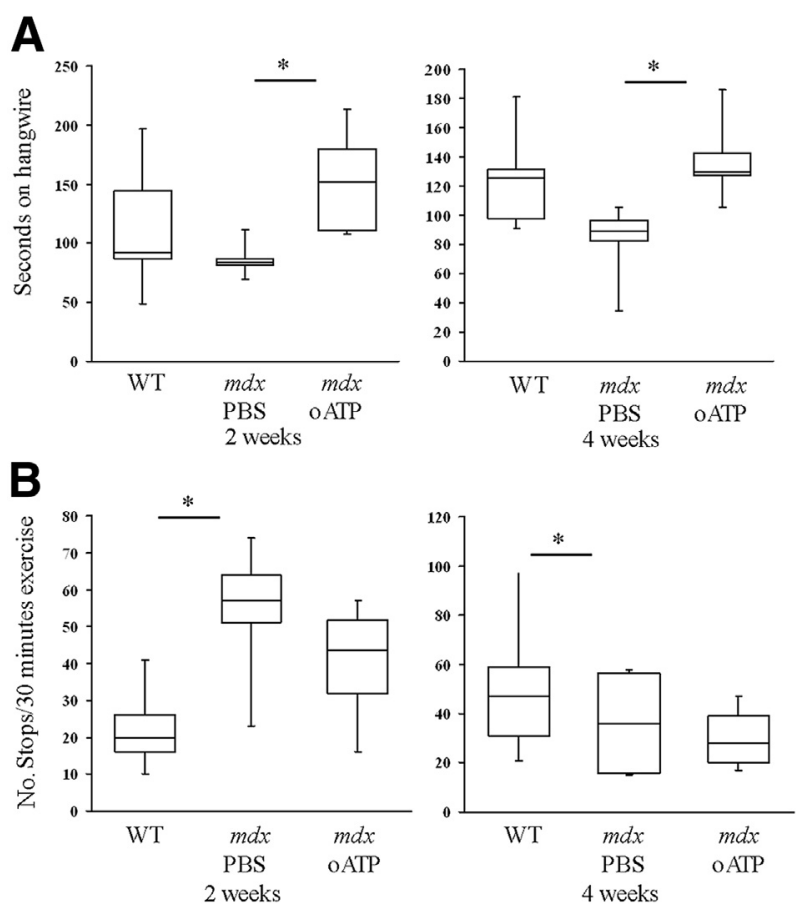

Figure 3 OATP improves muscle strength and fatigue resistance of $m d x-4 \mathrm{CV}$ mice. A: Hangwire test was performed on $m d x$ OATP, $m d x$ PBS, and age-matched WT control mice at the end of the second and fourth week of treatment. B: Treadmill test was performed on $m d x$ OATP, $m d x$ PBS, and age-matched WT control mice throughout the length of treatment. At the end of the second and fourth week the number of stops were measured by the experimenter. Each box represents the median with first and third quartile. $n=5$ mice. Statistical analysis was performed with the $U$ test. ${ }^{*} P<0.05 . m d x$ oATP, oATP-treated $m d x-4 C v$; $m d x$ PBS, untreated $m d x-4 C v$; oATP, periodate-oxidized ATP; PBS, phosphate-buffered saline; WT, wild-type.

(median, 10,740 U/L; first to third Q, 7460 to $33,480 \mathrm{U} / \mathrm{L}$; $n=5$ ) and oATP- $m d x-4 \mathrm{Cv}$ (median, $6030 \mu / \mathrm{mL}$; first to third $\mathrm{Q}, 4465$ to $11,195 \mathrm{U} / \mathrm{L} ; n=10 ; P<0.043$ ) (Figure $2 \mathrm{~A}$ ).

Hence, we treated exercised mice for four consecutive weeks at the same dose. $M d x-4 \mathrm{Cv}$ mice injected with vehicle alone and a group of age- and sex-matched WT C57B1/6 mice injected with vehicle alone or oATP served as controls. According to the standard operating procedure of preclinical drug testing in the $m d x$ mouse model, all of the experimental groups were subjected to chronic exercise by treadmill running throughout the treatment period. ${ }^{26}$ The mice were weighed at the beginning (baseline) of the treatment and then on a weekly basis. We did not detect any substantial difference between the various groups (data not shown).

Serum CK concentrations were evaluated at midpoint and at the end of treatment; at 2 weeks, oATP decreased serum CK concentrations by $44 \%$ (PBS- $m d x$ : median, $2530 \mathrm{U} / \mathrm{L}$; first to third Q, 2225 to $3470 \mathrm{U} / \mathrm{L} ; n=5$; oATP- $m d x$-4Cv: median, $1420 \mathrm{U} / \mathrm{L}$; first to third Q, 945 to $1775 \mathrm{U} / \mathrm{L} ; n=5 ; P<0.030$ ). The effect was maintained at 4 weeks with a $42 \%$ reduction in the oATP-treated group (PBS- $m d x$ : median, $3100 \mathrm{U} / \mathrm{L}$; first to third Q, 2315 to $4920 \mathrm{U} / \mathrm{L} ; n=5$; oATP- $m d x-4 \mathrm{Cv}$ : median, $1800 \mathrm{U} / \mathrm{L}$; first to third Q, 1610 to $1880 \mathrm{U} / \mathrm{L}$; $n=5$ ) (Figure 2B). We did not observe any effect of oATP on serum CK concentrations in the WT group
(PBS-WT: median, $545 \mathrm{U} / \mathrm{L}$; first to third Q, 440 to 600 $\mathrm{U} / \mathrm{L} ; n=4$; oATP-WT: median, $655 \mathrm{U} / \mathrm{L}$; first to third Q, 575 to $670 \mathrm{U} / \mathrm{L} ; n=4)$.

The evaluation of fatigue resistance and muscle strength at the end of the second and fourth week of treatment revealed that oATP resulted into an improved functional performance by hangwire testing and aerobic capacity (number of stops during running test) compared with PBS-treated mice (Figure 3, A and B).

\section{Targeting P2X Signaling in Vivo Ameliorates Structural Features in $m d x$ Mice}

Histologic analyses by H\&E staining were completed on GN, A.Tib., and diaphragms. A degenerated muscle status in PBStreated $m d x-4 \mathrm{Cv}$ mice was revealed, with different signs of myopathic damage, including muscle fiber degeneration with centralized nuclei, increased variability in fiber diameter, and presence of inflammation. P2X antagonism resulted in a decrease in the number and area of the inflammatory reactions surrounding the muscle cells in necrosis, which reached statistical significance in A.Tib. (Figure 4, A and B, and Supplemental Table S2). The beneficial effect of purinergic antagonism was associated with a reduction of centralized nuclei in all investigated muscular sites (Figure 5A and Supplemental Table S3). When the distribution of frequencies of myofiber CSAs was investigated, in oATP-treated mice we observed a decrease of the heterogeneity of CSAs that was observed in PBS-treated $m d x-4 \mathrm{Cv}$ mice, in which the largest diameters were a sign of degeneration (pathologic hypertrophy) (Figure 5B). Indeed, in the oATP group, CSA values showed a shift toward those observed in WT mice (Figure 5B) and displayed a $12.8 \%$ (A.Tib.) to a $36.7 \%$ (diaphragms) decrease of fiber size variability, $P<0.01$ (Supplemental Table S3).

To further analyze the extent of muscle membrane damage and myofiber degeneration, we used the EBD agent. This compound is a membrane-impermeant molecule that binds to serum albumin and is physically restricted from fibers unless the integrity of the skeletal muscle membrane is disrupted. ${ }^{27}$ When analyzed under the microscope, EBD emits a red autofluorescent signal. Hence, we injected EBD intraperitoneally in PBS- and oATP-treated $m d x-4 \mathrm{Cv}$ mice at 20 hours before the sacrifice. The strong red fluorescent signal detected in GN frozen sections was reduced in oATP-treated mice by a $48 \%$ (PBS- $m d x-4 \mathrm{Cv}$ : median, $0.95 \mathrm{EBD}^{+}$myofibers $/ \mathrm{mm}^{2}$; first to third Q, 0.80 to $1.61 \mathrm{EBD}^{+}$myofibers $/ \mathrm{mm}^{2} ; n=5$; oATP$m d x$-4Cv: median, $0.50 \mathrm{EBD}^{+}$myofibers $/ \mathrm{mm}^{2}$; first to third $\mathrm{Q}$, 0.21 to $1.08 \mathrm{EBD}^{+}$myofibers $/ \mathrm{mm}^{2} ; n=5$ ) (Figure 6).

\section{Targeting P2X Signaling in Vivo Reduces the Severity of the Inflammatory Innate Response}

The effect of oATP on the composition of the immune cells of the reactive inflammatory infiltrates was evaluated by serial immunostainings of GN and A.Tib. muscles with anti CD45 (lympho/monocytic marker) and anti F4/80 (macrophage 
A
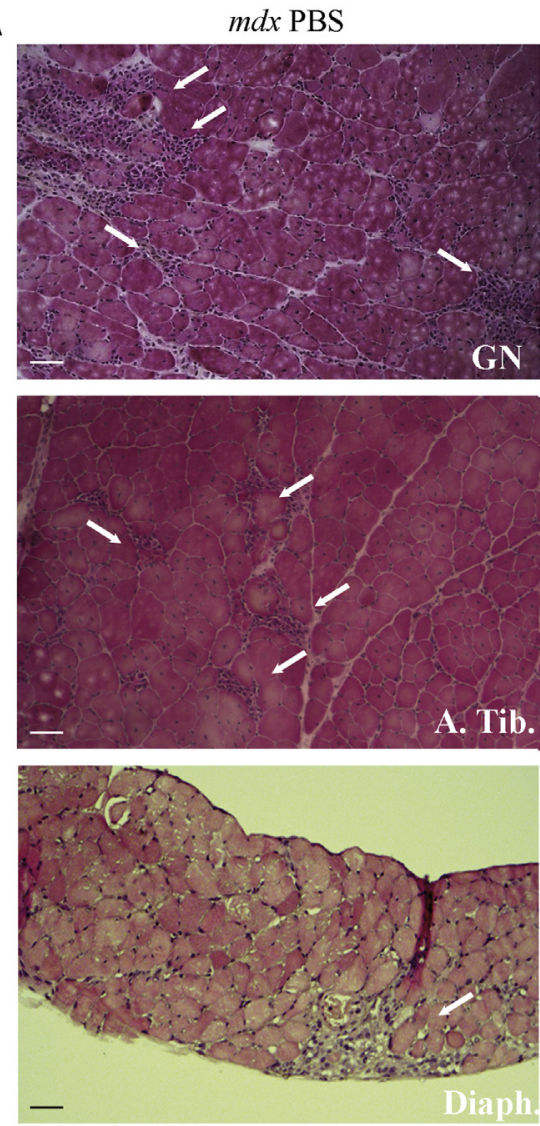

B
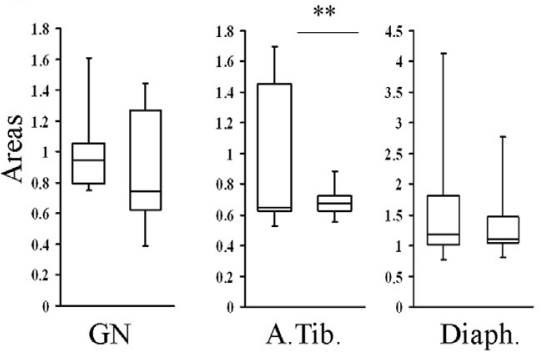
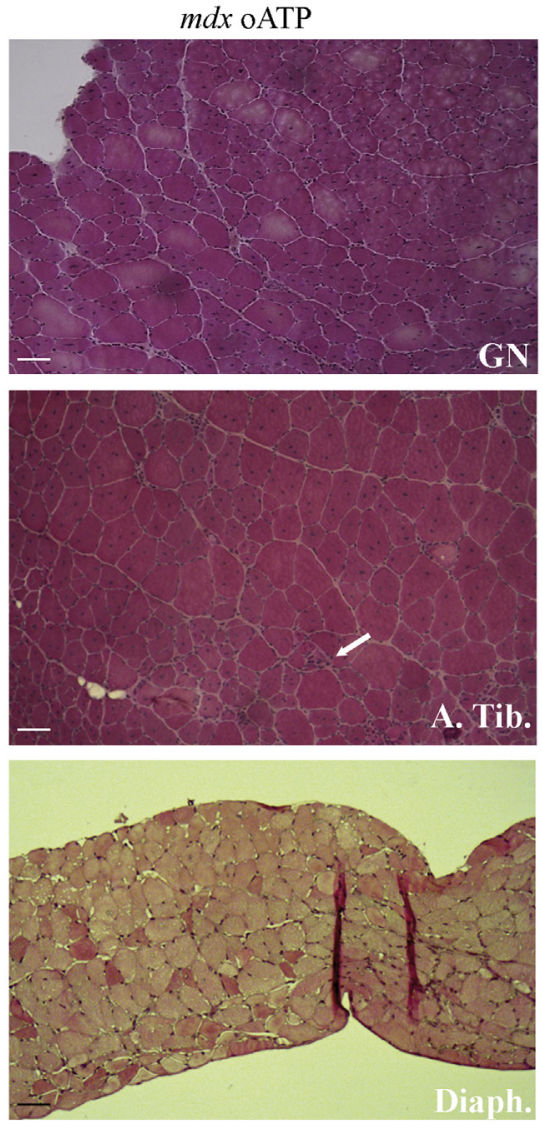

Figure 4 oATP improves the extension of reactive inflammatory infiltrates in $m d x-4 C v$ mice. A: Frozen GN, A.Tib., and Diaph. muscle tissue sections from $m d x$ oATP and $m d x$ PBS mice were collected at the fourth week of treatment and stained with standard H\&E technique. White arrows indicate inflammatory infiltrates. Representative images are shown. B: Graphical output of the areas and number of inflammatory infiltrates/ $\mathrm{mm}^{2}$ of total section area of muscles represented in $\mathbf{A}$. Each box represents the median with first and third quartile. $n=5$ mice for each experimental group. Statistical analysis was performed with the $U$ test. ${ }^{* \star} P<0.01$. Scale bar $=50 \mu \mathrm{m}$. Original magnification, $\times 10$. A.Tib., anterior tibialis; Diaph, paraffin-embedded diaphragm; GN, gastrocnemii; H\&E, hematoxylin and eosin; $m d x$ oATP, oATP-treated $m d x-4 C v ; m d x$ PBS, untreated $m d x-4 C v ;$ oATP, periodate-oxidized ATP; PBS, phosphate-buffered saline; WT, wild-type. marker) antibodies. Positive cells were manually counted in the whole area of the tissue section for each mouse and expressed as number of cells per square millimeter $\left(\mathrm{mm}^{2}\right)$. Interestingly and consistently with previous observations in chronic inflammatory diseases, administration of oATP led to a $43 \%$ decrease in the number of muscle-infiltrating $\mathrm{CD}^{+} 5^{+}$cells and a $31 \%$ reduction of $\mathrm{F} 4 / 80^{+}$macrophages (Figure $7, \mathrm{~A}$ and $\mathrm{B}$, and Supplemental Table S4). ${ }^{31-34}$ The beneficial effects of oATP on tissue inflammation were also reflected on IL-6 protein concentrations, which were significantly reduced by immunoblot in oATP-treated mice (Figure 7C).

\section{Treg Expansion in oATP-Treated $m d x$ Mice and Improvement of Muscle Regeneration}

We observed a $24 \%$ reduction of muscle-infiltrating $\mathrm{CD}^{+}$ $\mathrm{T}$ cells in oATP-treated mice (Figure 8, A and B, and
Supplemental Table S4). However, despite the muscle T-cell decrease, Foxp $3^{+}$cells were significantly increased by IHC in $m d x-4 \mathrm{Cv}$ mice treated with oATP compared with $m d x-4 \mathrm{Cv}$ mice treated with $\mathrm{PBS}$, indicating that pharmacologic P2X antagonism resulted in Treg enrichment in $m d x$ skeletal muscle (Figure 8, A and B, and Supplemental Table S4). The increase of Tregs among infiltrating $\mathrm{T}$ cells was further confirmed by the quantification of the transcript levels of Foxp3 and Areg, a growth factor that is expressed by a specialized population of Tregs detected in muscle tissue. Areg is upregulated during inflammation and participates in defensive and repair mechanisms (the so-called immune type 2 responses) (Figure 8C). 23,35,36

Because Areg was shown to display a direct effect on myofiber regeneration, the number of regenerative cells in the two experimental groups was quantitated by immunostaining for e-MYHC. e-MYHC ${ }^{+}$myofibers were manually 
counted in the whole area of the sections for each mouse and expressed as number of regenerative cells per square millimeter $\left(\mathrm{mm}^{2}\right)$. Notably, oATP induced a $10-$ and 3.4fold increase in the number of regenerative cells, respectively, in the GN and A.Tib. muscles (Figure 9,
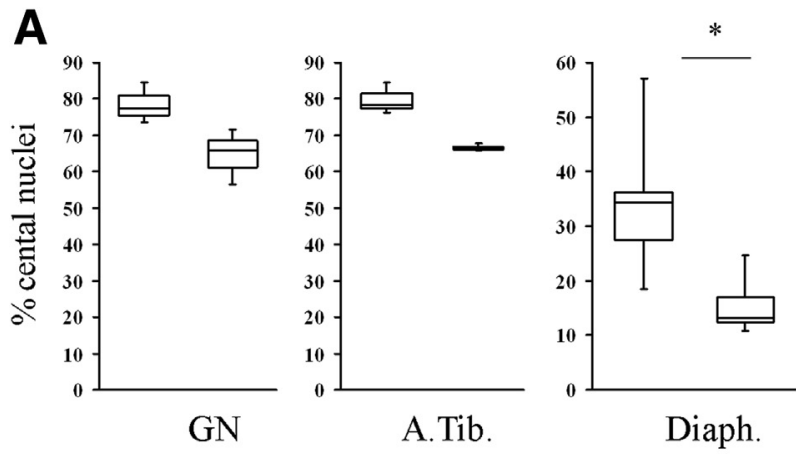

B

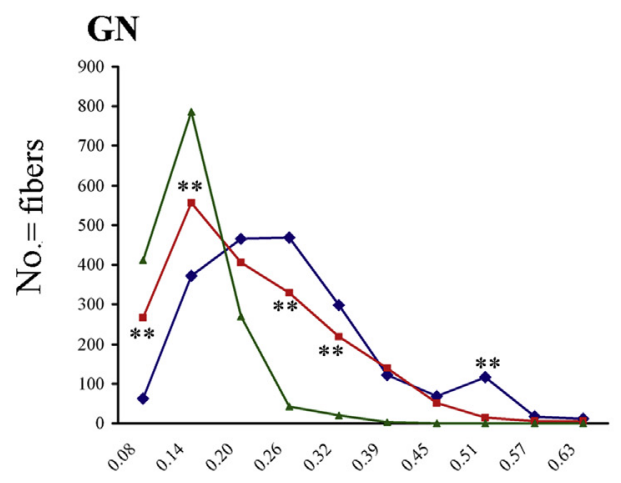

A. Tib.

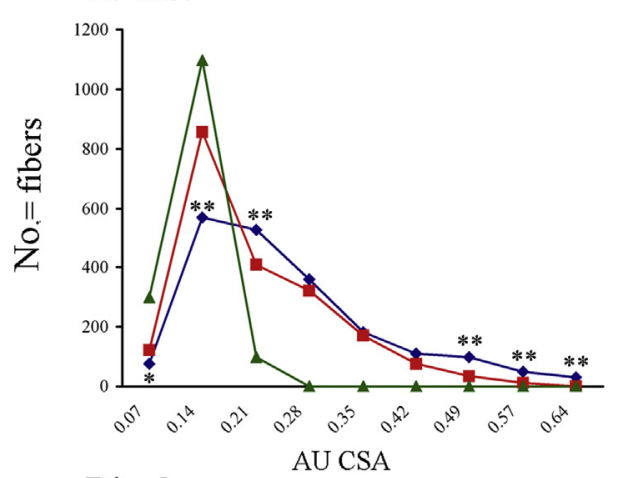

Diaph.

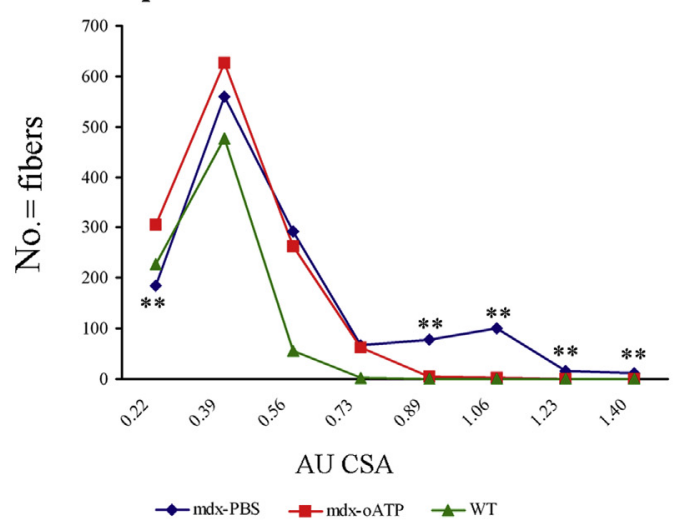

A and B, and Supplemental Table S5), and the number of $\mathrm{Foxp}^{+}$and $\mathrm{eMYHC}^{+}$cells significantly correlated ( $\mathrm{rs}=0.80$; $n=4$ mice per experimental group).

In accordance to the e-MYHC results, diaphragms isolated from oATP-treated mice displayed a 2.6-fold increase of cells positive for myogenin (a marker of early differentiating myoblasts) (Figure 9, A and B).

Conversely to this pro-regenerative image, $\mathrm{P} 2 \mathrm{X}$ blockade led to a reduction of fibrogenic factors, which ultimately stimulate endomysial fibrosis and connective replacement of muscle tissue. TGF- $\beta$ and CTGF protein levels were quantified in total muscle lysates isolated from GN of WT, PBS-, and oATP-treated mice $(n=3$ for each experimental group). As expected, TGF- $\beta$ protein levels were increased in untreated $m d x-4 \mathrm{Cv}$ mice compared with WT mice. ${ }^{37}$ However, this effect was reduced by $40 \%$ in the oATP-treated group. A similar result was observed for CTGF, one downstream effector of TGF- $\beta$, which was reduced by $60 \%$ (Figure 9C). These results suggest that pharmacologic P2X antagonism can improve dystrophic muscle regeneration and correlates with enhanced muscle Treg function.

\section{Discussion}

Appreciation is growing that, in DMD, the muscle membrane instability caused by dystrophin-dystrophin glycoprotein complex alterations and the consequent necrotic cell death result in the release of intracellular DAMPs. These DAMPs in turn recruit inflammatory cells with consequent oxidation of extracellular debris, internalization and presentation of antigens by professional antigen-presenting cells, and finally adaptive immune system activation. ${ }^{38}$ In muscle, ATP abundance inside cells and its virtual absence in the interstitial space render it an ideal harbinger of tissue damage. Here, we have provided evidence that pharmacologic inhibition of eATP signaling via P2X receptors improves muscular function and structure and enhances myofiber regeneration in $m d x$ mice. The beneficial effect exerted by purinergic blockade is associated with inhibition of the innate immune response and shaping of the muscular T-cell pool composition with selective increase of the Treg subset.

\footnotetext{
Figure 5 oATP ameliorates dystrophic features in $m d x-4 C v$ mice. Frozen GN, A.Tib., and Diaph. muscle tissue sections from $m d x$ oATP and $m d x$ PBS mice were collected at the fourth week of treatment and stained with standard H\&E technique. A: The number of central nuclei was quantified in 600 fibers of three consecutive sections for each muscle in GN, A.Tib., and Diaph. and expressed as percentage of total nuclei. B: The distribution of CSA values was evaluated in three consecutive sections in GN, A.Tib., and Diaph. muscles from oATP-treated (green line), untreated (red line) $m d x$ $4 \mathrm{CV}$, and WT mice (blue line). $n=5$ mice for each experimental group. Statistical analysis was performed with the $\chi^{2}$ test with Bonferroni correction. ${ }^{*} P<0.05,{ }^{*} P<<0.01$. A.Tib., anterior tibialis; CSA, crosssectional area; Diaph, paraffin-embedded diaphragm; GN, gastrocnemii; $\mathrm{H} \& \mathrm{E}$, hematoxylin and eosin; $m d x$ oATP, oATP-treated $m d x-4 C \mathrm{C} ; m d x$ PBS, untreated $m d x-4 C v$; oATP, periodate-oxidized ATP; PBS, phosphatebuffered saline; WT, wild-type.
} 

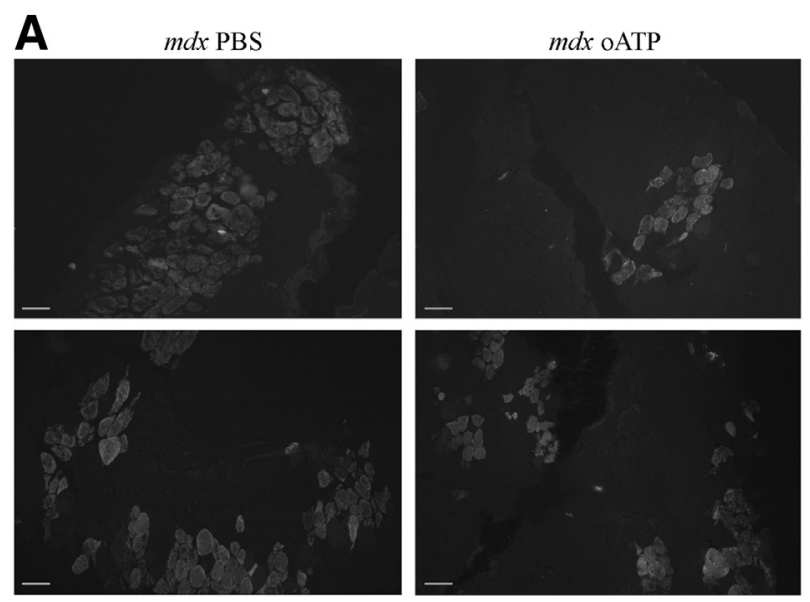

B

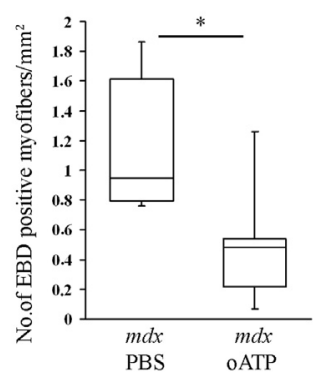

Figure 6 OATP reduces muscle degeneration and necrotic features in $m d x$ $4 C v$ mice. A: EBD agent was injected intraperitoneally in untreated (saline only) and oATP-treated $m d x$ mice 20 hours before the sacrifice to evaluate muscle fiber damage. Frozen GN muscle sections were examined by fluorescence microscopy. Damaged myofibers were visualized by a strong red autofluorescent signal that was reduced in the oATP group. Representative images are shown. B: $\mathrm{EBD}^{+}$muscle fibers were quantified in the whole area of two sections for each muscle and expressed as number per $\mathrm{mm}^{2}$ of total section area. Each box represents the median with first and third quartile. $n=5$ mice for each experimental group. Statistical analysis was performed with the $U$ test. ${ }^{*} P<0.05$. Scale bar $=50 \mu \mathrm{m}$. Original magnification, $\times 10$. EBD, Evans Blue Dye; GN, gastrocnemii; OATP, periodate-oxidized ATP; PBS, phosphate-buffered saline; WT, wild-type.

In the immune system P2X7 activation contributes to inflammasome activation and determines the release of inflammatory cytokines, including IL-1 $\beta$ and IL-18. Indeed, P2X antagonists reduce Il-1 $\beta$ release by lipopolysaccharideactivated macrophages and inhibit reactive oxygen species production and phagocytosis. ${ }^{39-41}$

Remarkably, in addition, muscle cells express key components of the inflammasome pathway, suggesting that they can exert a direct role in the development and maintenance of the inflammatory response. In primary myoblasts isolated from dysferlin-deficient patients and mice, eATP triggers P2X7-mediated activation of phosphatidylcholine-specific phospholipase $\mathrm{C}$ and A2 and secretion of IL-1 $\beta .^{21}$ Our results indicate a pathogenetic potential of eATP in $m d x$ mice as suggested by the improvement of muscular strength and structure by systemic oATP administration associated with a substantial reduction of inflammatory infiltrates and a decrease of IL-6 in muscles.

However, in addition to the well-documented role of $\mathrm{P} 2 \mathrm{X} 7$ in inflammasome activation in cells of the innate immune system,
P2X receptors were shown to participate in a feed-forward loop, which contributes to productive T-cell activation. This signaling is inhibited by oATP, which dampens proinflammatory T-cell differentiation and ameliorates immunopathologic tissue damage in several experimental models of autoimmunity. ${ }^{29-32}$ In addition, oATP determines the functional polarization of naive $\mathrm{CD} 4$ cells to adaptive Tregs on T-cell receptor stimulation. ${ }^{22,42,43}$

In $m d x$ mice blockade of the eATP/P2X axis resulted in a $24 \%$ decrease of $\mathrm{CD}^{+}$cells and an 1.8-fold increase of Foxp $3^{+}$ cells in muscle, indicating that purinergic antagonism affected the composition of the T-cell pool in dystrophic muscles and increased the abundance of proregenerative Tregs. In the context of the immune response, Foxp3-expressing Tregs are specialized CD4 cells, which crucially contribute to tissues integrity and whose dysfunction was linked to several immunopathologic conditions. ${ }^{44}$ Tregs are also characterized by the combined expression of CD39 and CD73 ectonucleotidases,
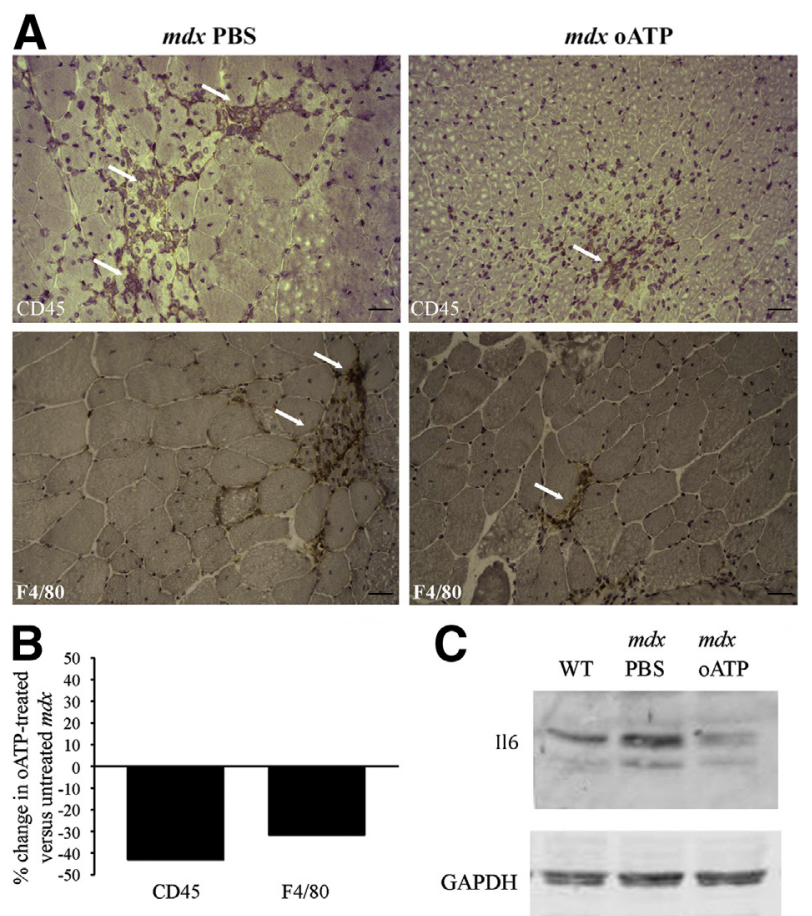

Figure 7 Effects of oATP on innate immunity in $m d x-4 C v$ mice. A: Frozen GN and A.Tib. muscle sections from $m d x$ oATP and $m d x$ PBS mice were immunostained with primary antibody directed toward CD45 and F4/80 (white arrows). Representative images of GN are shown. B: In GN, $\mathrm{CD} 45^{+}$and $\mathrm{F} 4 / 80^{+}$ fibers were quantified in the whole area of the tissue section and expressed as number of positive cells $/ \mathrm{mm}^{2}$ of section area. C: GN skeletal muscle lysates from $m d x$ OATP and $m d x$ PBS were subjected to immunoblot analysis with specific antibodies against IL-6. Determination of GAPDH expression was used to normalize sample loading. Representative images are shown. Each column represents the mean percentage change in oATP-treated versus untreated $m d x-4 C v$ mice. $n=5$ mice for each experimental group (B); $n=3$ mice for each experimental group (C). Statistical analysis was performed with the $U$ test. Scale bar $=20 \mu \mathrm{m}$. Original magnification, $\times 20$. A.Tib., anterior tibialis; $\mathrm{GAPDH}$, glyceraldehyde-3-phosphate dehydrogenase; GN, gastrocnemii; $m d x$ oATP, oATP-treated $m d x-4 C v$; $m d x$ PBS, untreated $m d x-4 C v$; oATP, periodateoxidized ATP; PBS, phosphate-buffered saline; WT, wild-type. 

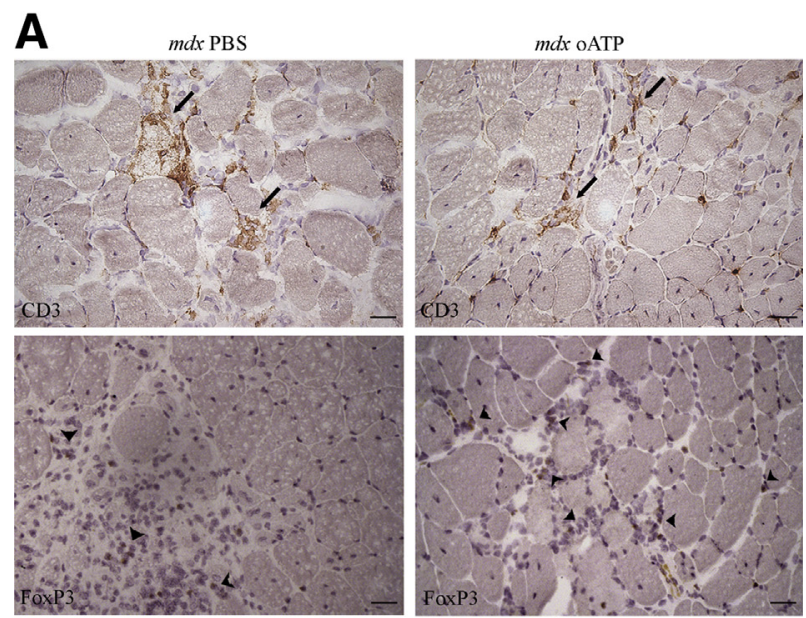

B

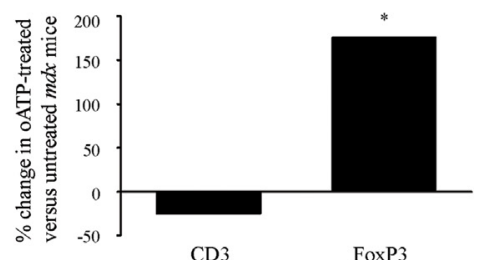

C
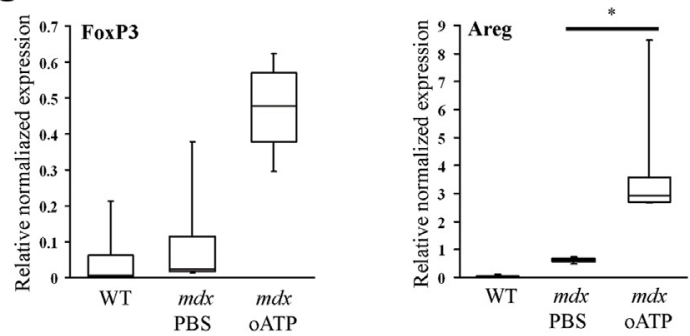

Figure 8 Effects of oATP on adaptive immunity in $m d x-4 C v$ mice. A: Frozen GN and A.Tib. muscle sections from $m d x$ OATP and $m d x$ PBS were immunostained with primary antibody directed toward CD3 (black arrows) and Foxp3 (black arrowheads). Representative images of GN are shown. B: In $\mathrm{GN}, \mathrm{CD}^{+}$and Foxp3 $3^{+}$lymphocytes were quantified in the whole area of the tissue section and expressed as number of positive cells $/ \mathrm{mm}^{2}$ of section area. Each column represents the mean percentage change in oATP-treated versus untreated $m d x-4 C v$ mice. C: Total RNA was isolated from GN skeletal muscle lysates from $m d x$ oATP and $m d x$ PBS mice and reverse transcribed. Foxp3 and Areg transcripts were quantified by quantitative real-time PCR. Each box represents the median with first and third quartile. $n=5$ mice for each experimental group. Statistical analysis was performed with the $U$ test. ${ }^{*} P<0.05$. Scale bar $=20 \mu \mathrm{m}$. Original magnification, $\times 20$. Areg, amphyregulin; A.Tib., anterior tibialis; GN, gastrocnemii; $m d x$ oATP, oATPtreated $m d x-4 \mathrm{Cv}$; $m d x$ PBS, untreated $m d x-4 C v$; oATP, periodate-oxidized ATP; PBS, phosphate-buffered saline; WT, wild-type.

which rapidly degrade eATP to adenosine. ${ }^{45-47}$ The exclusive immunosuppressive properties of Tregs have prompted a number of attempts to exploit them in cell therapy protocols both in murine models of autoimmunity and human graftversus-host disease. ${ }^{48,49}$ The safety and feasibility of the adoptive transfer of Tregs is currently being tested in clinical trials focused on inflammation and rejection in liver and kidney transplantation and on type 1 diabetes (http://www. clinicaltrials.gov; accession numbers NCT02088931, NCT02145325, NCT01210664, NCT02188719, and NCT01624077).
In muscle, increased Foxp3 expression was observed in $m d x$ mice concomitantly with increased strength and reduced diaphragm and cardiac fibrosis. ${ }^{50}$ Analogously, Tregs were shown to accumulate in the muscle infiltrates of
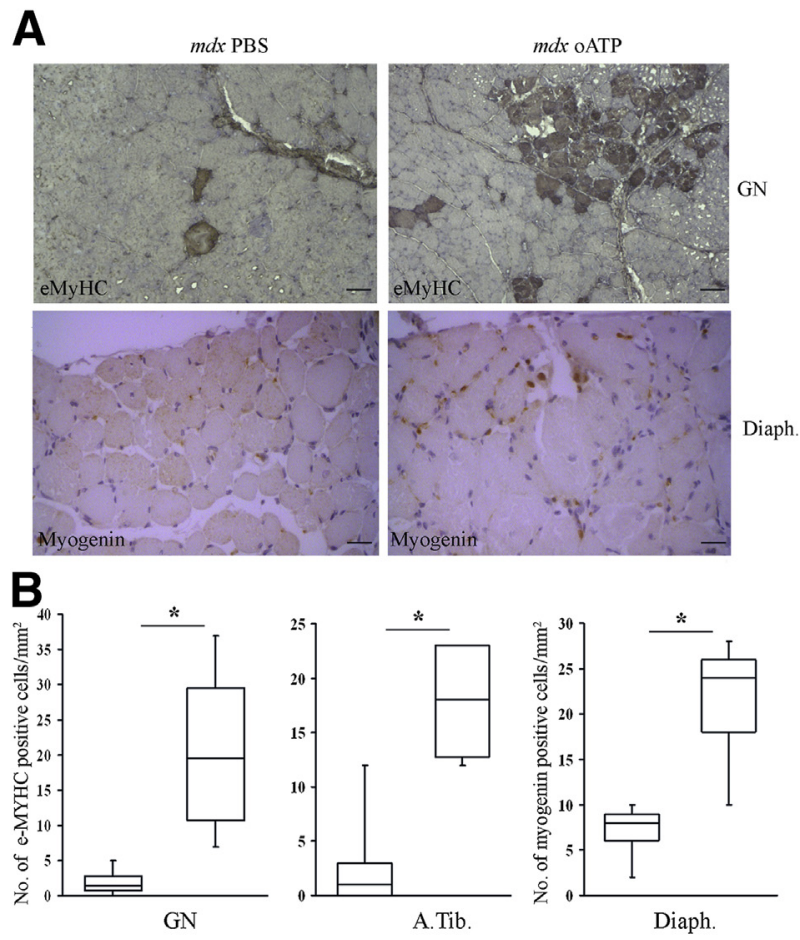

C

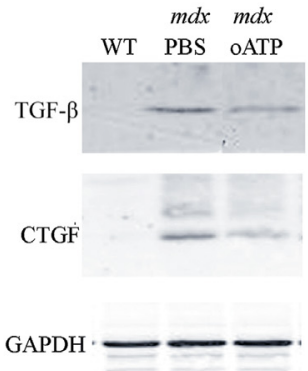

Figure 9 oATP enhances myofiber regeneration and inhibits the expression of the profibrotic factors TGF- $\beta$ and CTGF. A: Frozen GN and A.Tib. muscle sections from $m d x$ oATP and $m d x$ PBS mice were immunostained with primary antibody directed toward the native form of e-MyHC. Representative images of GN are shown. Paraffin-embedded Diaph. sections from $m d x$ oATP and $m d x$ PBS mice were immunostained with primary antibody directed toward myogenin. Representative images are shown. B: E-MYHC ${ }^{+}$and myogenin ${ }^{+}$fibers were quantified in the whole area of the tissue sections. C: GN skeletal muscle lysates from $m d x$ OATP and $m d x$ PBS mice were subjected to immunoblot analysis with specific antibodies against TGF- $\beta$ and CTGF. Determination of GAPDH expression was used to normalize sample loading. Representative images are shown. Each box represents the median with first and third quartile (B). $n=5$ mice for each experimental group (B); $n=3$ mice per experimental group $(\mathbf{C})$. Statistical analysis was performed with the $U$ test. ${ }^{*} P<0.05$. Scale bars: $50 \mu \mathrm{m}(\mathbf{A}, \mathrm{GN}) ; 20 \mu \mathrm{m}$ (A, Diaph.) Original magnification: $\times 10(\mathbf{A}, \mathrm{GN}) ; \times 20($ A, Diaph.). A.Tib., anterior tibialis; CTGF, connective tissue growth factor; Diaph., diaphragm; eMyHC, embryonal myosin heavy chain; GAPDH, glyceraldehyde phosphate dehydrogenase; GN, gastrocnemii; $m d x$ oATP, oATP-treated $m d x-4 C v$; $m d x$ PBS, untreated $m d x$ 4CV; oATP, periodate-oxidized ATP; PBS, phosphate-buffered saline; TGF, transforming growth factor; WT, wild-type. 
$m d x$ mice where they exerted a protective role on muscle pathology and promoted muscle repair. ${ }^{23,24}$ On one side, Tregs were shown to regulate the myeloid populations that infiltrate the degenerative tissue and to induce their shift from a pro- to an anti-inflammatory phenotype. On the other side, Tregs exerted a direct stimulatory effect on satellite cells by expressing Areg, which enhances satellite cell differentiation in vivo and in vitro. ${ }^{23}$

Along this line, in $m d x$ mice, improvement of muscle Tregs by oATP likely enhanced myoblast regeneration and resulted in decreased expression of profibrotic stimuli such as TGF- $\beta$ and CTGF.

Altogether, our data indicate a pleiotropic role of eATP and P2X signaling in the pathogenesis of dystrophic muscle destruction and point to pharmacologic P2X antagonism as a possible therapeutic strategy to ameliorate the prognosis of this devastating condition.

\section{Acknowledgments}

We thank Dr. Serena Baratto and Paolo Broda (Istituto Giannina Gaslini, Genova, Italy) for helpful technical advice.

\section{Supplemental Data}

Supplemental material for this article can be found at http://dx.doi.org/10.1016/j.ajpath.2015.08.010.

\section{References}

1. Bushby K, Finkel R, Birnkrant DJ, Case LE, Clemens PR, Cripe L, Kaul A, Kinnett K, McDonald C, Pandya S, Poysky J, Shapiro F, Tomezsko J, Constantin C; DMD Care Considerations Working Group: Diagnosis and management of Duchenne muscular dystrophy, part 2: implementation of multidisciplinary care. Lancet Neurol 2010, 9:177-189

2. Rando TA: The dystrophin-glycoprotein complex, cellular signaling, and the regulation of cell survival in muscular dystrophies. Muscle Nerve 2001, 24:1575-1594

3. Petrof BJ, Shrager JB, Stedman HH, Kelly AM, Sweeney HL: Dystrophin protects the sarcolemma from stresses developed during muscle contraction. Proc Natl Acad Sci U S A 1993, 90: $3710-3714$

4. Spencer MJ, Montecino-Rodriguez E, Dorshkind K, Tidball JG: Helper $(\mathrm{CD} 4(+))$ and cytotoxic $(\mathrm{CD} 8(+)) \mathrm{T}$ cells promote the pathology of dystrophin-deficient muscle. Clin Immunol 2001, 98: 235-243

5. Wehling-Henricks M, Sokolow S, Lee JJ, Myung KH, Villalta SA, Tidball JG: Major basic protein-1 promotes fibrosis of dystrophic muscle and attenuates the cellular immune response in muscular dystrophy. Hum Mol Genet 2008, 17:2280-2292

6. Hodgetts S, Radley H, Davies M, Grounds MD: Reduced necrosis of dystrophic muscle by depletion of host neutrophils, or blocking TNFalpha function with Etanercept in mdx mice. Neuromuscul Disord 2006, 16:591-602

7. De Luca A, Nico B, Liantonio A, Didonna MP, Fraysse B, Pierno S, Burdi R, Mangieri D, Rolland JF, Camerino C, Zallone A, Confalonieri P, Andreetta F, Arnoldi E, Courdier-Fruh I, Magyar JP,
Frigeri A, Pisoni M, Svelto M, Conte Camerino D: A multidisciplinary evaluation of the effectiveness of cyclosporine a in dystrophic mdx mice. Am J Pathol 2005, 166:477-489

8. Angelini C: The role of corticosteroids in muscular dystrophy: a critical appraisal. Muscle Nerve 2007, 36:424-435

9. Ermolova NV, Martinez L, Vetrone SA, Jordan MC, Roos KP, Sweeney HL, Spencer MJ: Long-term administration of the TNF blocking drug Remicade (cV1q) to mdx mice reduces skeletal and cardiac muscle fibrosis, but negatively impacts cardiac function. Neuromuscul Disord 2014, 24:583-595

10. Uaesoontrachoon K, Quinn JL, Tatem KS, Van Der Meulen JH, Yu Q, Phadke A, Miller BK, Gordish-Dressman H, Ongini E, Miglietta D, Nagaraju K: Long-term treatment with naproxcinod significantly improves skeletal and cardiac disease phenotype in the mdx mouse model of dystrophy. Hum Mol Genet 2014, 23: 3239-3249

11. Henriques-Pons A, Yu Q, Rayavarapu S, Cohen TV, Ampong B, Cha HJ, Jahnke V, Van der Meulen J, Wang D, Jiang W, Kandimalla ER, Agrawal S, Spurney CF, Nagaraju K: Role of Tolllike receptors in the pathogenesis of dystrophin-deficient skeletal and heart muscle. Hum Mol Genet 2014, 23:2604-2617

12. Bours MJ, Swennen EL, Di Virgilio F, Cronstein BN, Dagnelie PC: Adenosine 5'-triphosphate and adenosine as endogenous signaling molecules in immunity and inflammation. Pharmacol Ther 2006, 112: 358-404

13. Yegutkin GG, Henttinen T, Samburski SS, Spychala J, Jalkanen S: The evidence for two opposite, ATP-generating and ATP-consuming, extracellular pathways on endothelial and lymphoid cells. Biochem J 2002, 367:121-128

14. Rubartelli A, Lotze MT: Inside, outside, upside down: damageassociated molecular-pattern molecules (DAMPs) and redox. Trends Immunol 2007, 28:429-436

15. Trautmann A: Extracellular ATP in the immune system: more than just a "danger signal". Sci Signal 2009, 2:pe6

16. Pizzirani C, Ferrari D, Chiozzi P, Adinolfi E, Sandonà D, Savaglio E, Di Virgilio F: Stimulation of P2 receptors causes release of IL-1betaloaded microvesicles from human dendritic cells. Blood 2007, 109: 3856-3864

17. Buvinic S, Almarza G, Bustamante M, Casas M, Lopez J, Riquelme M, Saez JC, Huidobro-Toro JP, Jaimovich E: ATP released by electrical stimuli elicits calcium transients and gene expression in skeletal muscle. J Biol Chem 2009, 284:34490-34505

18. Jiang T, Yeung D, Lien CF, Górecki DC: Localized expression of specific P2X receptors in dystrophin-deficient DMD and mdx muscle. Neuromuscul Disord 2005, 15:225-236

19. Yeung D, Zablocki K, Lien CF, Jiang T, Arkle S, Brutkowski W, Brown J, Lochmuller H, Simon J, Barnard EA, Górecki DC: Increased susceptibility to ATP via alteration of P2X receptor function in dystrophic mdx mouse muscle cells. FASEB J 2006, 20: 610-620

20. Young CN, Brutkowski W, Lien CF, Arkle S, Lochmüller H, Zabłocki K, Górecki DC: P2X7 purinoceptor alterations in dystrophic mdx mouse muscles: relationship to pathology and potential target for treatment. J Cell Mol Med 2012, 16: 1026-1037

21. Rawat R, Cohen TV, Ampong B, Francia D, Henriques-Pons A, Hoffman EP, Nagaraju K: Inflammasome up-regulation and activation in dysferlin-deficient skeletal muscle. Am J Pathol 2010, 176: 2891-2900

22. Schenk U, Westendorf AM, Radaelli E, Casati A, Ferro M, Fumagalli M, Verderio C, Buer J, Scanziani E, Grassi F: Purinergic control of $\mathrm{T}$ cell activation by ATP released through pannexin-1 hemichannels. Sci Signal 2008, 1:ra6

23. Burzyn D, Kuswanto W, Kolodin D, Shadrach JL, Cerletti M, Jang Y, Sefik E, Tan TG, Wagers AJ, Benoist C, Mathis D: A special population of regulatory T cells potentiates muscle repair. Cell 2013, 155 : $1282-1295$ 
24. Villalta SA, Rosenthal W, Martinez L, Kaur A, Sparwasser T, Tidball JG, Margeta M, Spencer MJ, Bluestone JA: Regulatory T cells suppress muscle inflammation and injury in muscular dystrophy. Sci Transl Med 2014, 6:258ra142

25. Di Virgilio F: Novel data point to a broader mechanism of action of oxidized ATP: the P2X7 receptor is not the only target. Br J Pharmacol 2003, 140:441-443

26. Grounds MD, Radley HG, Lynch GS, Nagaraju K, De Luca A: Towards developing standard operating procedures for pre-clinical testing in the mdx mouse model of Duchenne muscular dystrophy. Neurobiol Dis 2008, 31:1-19

27. Minetti GC, Colussi C, Adami R, Serra C, Mozzetta C, Parente V, Fortuni S, Straino S, Sampaolesi M, Di Padova M, Illi B, Gallinari P, Steinkühler C, Capogrossi MC, Sartorelli V, Bottinelli R, Gaetano C, Puri PL: Functional and morphological recovery of dystrophic muscles in mice treated with deacetylase inhibitors. Nat Med 2006, 12 : $1147-1150$

28. Klein SM, Vykoukal J, Lechler P, Zeitler K, Gehmert S, Schreml S, Alt E, Bogdahn U, Prantl L: Noninvasive in vivo assessment of muscle impairment in the mdx mouse model-a comparison of two common wire hanging methods with two different results. J Neurosci Methods 2012, 203:292-297

29. Gazzerro E, Assereto S, Bonetto A, Sotgia F, Scarfî S, Pistorio A, Bonuccelli G, Cilli M, Bruno C, Zara F, Lisanti MP, Minetti C: Therapeutic potential of proteasome inhibition in Duchenne and Becker muscular dystrophies. Am J Pathol 2010, 176:1863-1877

30. Swinscow TDV: Statistics at Square One. 9 ed. Revised by Campbell MJ. London: BMJ Publishing Group 1997.

31. Ardissone V, Radaelli E, Zaratin P, Ardizzone M, Ladel C, Gattorno M, Martini A, Grassi F, Traggiai E: Pharmacologic P2X purinergic receptor antagonism in the treatment of collagen-induced arthritis. Arthritis Rheum 2011, 63:3323-3332

32. Vergani A, Fotino C, D'Addio F, Tezza S, Podetta M, Gatti F, Chin M, Bassi R, Molano RD, Corradi D, Gatti R, Ferrero ME, Secchi A, Grassi F, Ricordi C, Sayegh MH, Maffi P, Pileggi A, Fiorina P: Effect of the purinergic inhibitor oxidized ATP in a model of islet allograft rejection. Diabetes 2013, 62:1665-1675

33. Vergani A, Tezza S, D’Addio F, Fotino C, Liu K, Niewczas M, Bassi R, Molano RD, Kleffel S, Petrelli A, Soleti A, Ammirati E, Frigerio M, Visner G, Grassi F, Ferrero ME, Corradi D, Abdi R, Ricordi C, Sayegh MH, Pileggi A, Fiorina P: Long-term heart transplant survival by targeting the ionotropic purinergic receptor P2X7. Circulation 2013, 127:463-475

34. Kurashima Y, Amiya T, Nochi T, Fujisawa K, Haraguchi T, Iba H, Tsutsui H, Sato S, Nakajima S, Iijima H, Kubo M, Kunisawa J, Kiyono H: Extracellular ATP mediates mast cell-dependent intestinal inflammation through P2X7 purinoceptors. Nat Commun 2012, 3: 1034

35. Zaiss DM, Gause WC, Osborne LC, Artis D: Emerging functions of amphiregulin in orchestrating immunity, inflammation, and tissue repair. Immunity $2015,42: 216-226$
36. Berasain C, Avila MA: Amphiregulin. Semin Cell Dev Biol 2014, 28 : $31-41$

37. Kharraz Y, Guerra J, Pessina P, Serrano AL, Muñoz-Cánoves P: Understanding the Process of Fibrosis in Duchenne muscular dystrophy. Biomed Res Int 2014, 2014:965631

38. Di Virgilio F: Liaisons dangereuses: P2X(7) and the inflammasome. Trends Pharmacol Sci 2007, 28:465-472

39. Zhu S, Wang Y, Wang X, Li J, Hu F: Emodin inhibits ATP-induced IL-1 $\beta$ secretion, ROS production and phagocytosis attenuation in rat peritoneal macrophages via antagonizing $\mathrm{P}_{2} \mathrm{X}_{7}$ receptor. Pharm Biol 2014, 52:51-57

40. Ikeda M, Tsuno S, Sugiyama T, Hashimoto A, Yamoto K, Takeuchi K Kishi H, Mizuguchi H, Kohsaka S, Yoshioka T: $\mathrm{Ca}(2+)$ spiking activity caused by the activation of store-operated $\mathrm{Ca}(2+)$ channels mediates TNF- $\alpha$ release from microglial cells under chronic purinergic stimulation. Biochim Biophys Acta 2013, 1833:2573-2585

41. Lemaire I, Falzoni S, Zhang B, Pellegatti P, Di Virgilio F: The P2X7 receptor and Pannexin-1 are both required for the promotion of multinucleated macrophages by the inflammatory cytokine GM-CSF. J Immunol 2011, 187:3878-3887

42. Schenk U, Frascoli M, Proietti M, Geffers R, Traggiai E, Buer J, Ricordi C, Westendorf AM, Grassi F: ATP inhibits the generation and function of regulatory $\mathrm{T}$ cells through the activation of purinergic P2X receptors. Sci Signal 2011, 4:ra12

43. Frascoli M, Marcandalli J, Schenk U, Grassi F: Purinergic P2X7 receptor drives $\mathrm{T}$ cell lineage choice and shapes peripheral $\gamma \delta$ cells. J Immunol 2012, 189:174-180

44. Sakaguchi S, Wing K, Miyara M: Regulatory T cells - a brief history and perspective. Eur J Immunol 2007, 37(Suppl 1):S116-S123

45. Borsellino G, Kleinewietfeld M, Di Mitri D, Sternjak A, Diamantini A, Giometto R, Höpner S, Centonze D, Bernardi G, Dell'Acqua ML, Rossini PM, Battistini L, Rötzschke O, Falk K: Expression of ectonucleotidase CD39 by Foxp3+ Treg cells: hydrolysis of extracellular ATP and immune suppression. Blood 2007, 110:1225-1232

46. Deaglio S, Dwyer KM, Gao W, Friedman D, Usheva A, Erat A, Chen JF, Enjyoji K, Linden J, Oukka M, Kuchroo VK, Strom TB Robson SC: Adenosine generation catalyzed by CD39 and CD73 expressed on regulatory $\mathrm{T}$ cells mediates immune suppression. J Exp Med 2007, 204:1257-1265

47. Kobie JJ, Shah PR, Yang L, Rebhahn JA, Fowell DJ, Mosmann TR: $\mathrm{T}$ regulatory and primed uncommitted CD4 T cells express CD73, which suppresses effector CD4 $\mathrm{T}$ cells by converting 5 '-adenosine monophosphate to adenosine. J Immunol 2006, 177:6780-6786

48. Miyara M, Ito Y, Sakaguchi S: TREG-cell therapies for autoimmune rheumatic diseases. Nat Rev Rheumatol 2014, 10:543-551

49. Beres AJ, Drobyski WR: The role of regulatory T cells in the biology of graft versus host disease. Front Immunol 2013, 4:163

50. Vetrone SA, Montecino-Rodriguez E, Kudryashova E, Kramerova I, Hoffman EP, Liu SD, Miceli MC, Spencer MJ: Osteopontin promotes fibrosis in dystrophic mouse muscle by modulating immune cell subsets and intramuscular TGF-beta. J Clin Invest 2009, 119:1583-1594 